\title{
Early Serotonergic Projections to Cajal-Retzius Cells: Relevance for Cortical Development
}

\author{
Skirmantas Janušonis, ${ }^{1 *}$ Vicko Gluncic, ${ }^{1 *}$ and Pasko Rakic ${ }^{1}$ \\ Yale University School of Medicine, Department of Neurobiology, New Haven, Connecticut 06520-8001
}

\begin{abstract}
Although the serotonergic system plays an important role in various neurological disorders, the role of early serotonergic projections to the developing cerebral cortex is not well understood. Because serotonergic fibers enter the marginal zone (MZ) before birth, it has been suggested that they may influence cortical development through synaptic contacts with Cajal-Retzius (CR) cells. We used immunohistochemistry combined with confocal and electron microscopy to show that the earliest serotonergic projections to the MZ form synaptic contacts with the somata and proximal dendrites of CR cells as early as embryonic day 17. To elucidate the functional significance of these early serotonergic contacts with CR cells, we perturbed their normal development by injecting pregnant mice with 5-methoxytryptamine. Lower reelin levels were detected in the brains of newborn pups from the exposed animals. Because reelin plays an important role in the cortical laminar and columnar organization during development, we killed some pups from the same litters on postnatal day 7 and analyzed their presubicular cortex. We found that the supragranular layers of the presubicular cortex (which normally display a visible columnar deployment of neurons) were altered in the treated animals. Our results suggest a mechanism of how serotonergic abnormalities during cortical development may disturb the normal cortical organization; and, therefore, may be relevant for understanding neurological disorders in which abnormalities of the serotonergic system are accompanied by cortical pathology (such as autism).
\end{abstract}

Key words: serotonin (5-HT); Cajal-Retzius cells; reelin; autism; microcolumns; marginal zone

\section{Introduction}

The serotonergic system plays an important role in various developmental neurological disorders (Azmitia, 2001; WhitakerAzmitia, 2001); however, the role of early serotonergic projections to the developing cortex before birth is not well understood. Previous light microscopy studies have shown that, after reaching the neocortex, serotonergic afferents form two bands, one in the marginal zone (MZ) above the cortical plate and the other below the cortical plate, before they massively invade the cortical plate itself (Lidov and Molliver, 1982; Wallace and Lauder, 1983; Bruning et al., 1997; Verney et al., 2002). In the mouse and rat, the first serotonergic fibers in the developing neocortex appear around embryonic day 16-17 (E16-17) (Wallace and Lauder, 1983; Bruning et al., 1997). Because early serotonergic projections target the MZ, it has been suggested that they may play an important role in cortical development (Whitaker-Azmitia et al., 1996; Persico et al., 2003). Specifically, it has been proposed that they may form contacts with Cajal-Retzius (CR) cells (Radnikow et al., 2002), but no actual synaptic contacts have so far been demonstrated. CR cells are located in the MZ and are considered to be

\footnotetext{
Received 0ct. 14, 2003; revised Dec. 16, 2003; accepted Dec. 21, 2003.

This work was supported by a National Alliance for Autism Research postdoctoral fellowship (S.J.) and the United States Public Health Service (P.R.). We thank Klara Szigeti for technical assistance with electron microscopy and Drs. Bridget Berechid and Kresimir Letinic for advice with Western blots. We thank Dr. Constantinos D. Paspalas for his suggestions and comments on this manuscript.

*S.J. and V.G. contributed equally to this work.

Correspondence should be addressed to Dr. Pasko Rakic, Yale University School of Medicine, Department of Neurobiology, P.0. Box 208001, New Haven, CT 06520-8001. E-mail: pasko.rakic@yale.edu.

DOI:10.1523/JNEUROSCI.4651-03.2004

Copyright $\odot 2004$ Society for Neuroscience $\quad$ 0270-6474/04/241652-08\$15.00/0
}

necessary for the correct positioning of neurons in cortical layers (Ogawa et al., 1995; Marín-Padilla, 1998; Dulabon et al., 2000; Hack et al., 2002; Ang et al., 2003; Rakic and Zecevic, 2003), as well as in radial columns (Nishikawa et al., 2002; Luhmann et al., 2003). Because microcolumns are basic anatomical and functional units of the cerebral cortex (Jones, 2000; Buxhoeveden and Casanova, 2002), their abnormalities underlie several neurological disorders in humans. Specifically, the evidence that the serotonergic system is disturbed in several debilitating neurological disorders, such as autism and schizophrenia (Anderson et al., 1990; Chugani et al., 1999; Chugani, 2002; Dean, 2003), has been recently complemented by reports of cortical columnar pathology in some of these disorders (Casanova et al., 2002a,c). Interestingly, the levels of reelin, a glycoprotein produced by CR cells, are also abnormal in some of these disorders (Fatemi et al., 2001a,b, 2002; Fatemi, 2002; Eastwood and Harrison, 2003).

Based on these studies, we hypothesized that an abnormal serotonergic input to CR cells may have an effect on the late stages of embryonic cortical development. To test this hypothesis, we first investigated whether serotonergic afferents to the $\mathrm{MZ}$ make synapses with CR cells, and, second, whether manipulation of the serotonin system can affect reelin expression and lead to anatomical disturbances of the mouse cerebral cortex.

\section{Materials and Methods}

Animals. Timed-pregnant mice (CD-1) were obtained from Charles River Laboratories (Wilmington, MA) and housed in a mouse facility until used for experiments. All procedures have been approved by the Yale University Animal Care and Use Committee and were in compli- 
ance with the Policies on the Use of Animals and Humans in Neuroscience Research approved by the Society for Neuroscience.

Fluorescent confocal microscopy. Brains of E17 embryos were extracted and immersion-fixed in $4 \%$ paraformaldehyde overnight. They were cryoprotected in 30\% sucrose, embedded in Tissue-Tek O.C.T. compound (Sakura Finetek, Inc., Torrance, CA) and cut coronally on a cryostat at 30-40 $\mu \mathrm{m}$. The sections (on slides or free-floating) were then processed with immunohistochemistry. They were rinsed in $0.1 \mathrm{M}$ PBS, $\mathrm{pH} 7.4$, blocked in 3-5\% normal donkey serum (NDS) and $0.5-1 \%$ Triton X-100 in PBS, and incubated in 1:200 rabbit anti-5-HT (catalog \#NT102; Protos Biotech Corporation, New York, NY) and 1:100 mouse anti-reelin (a gift of Dr. M. Ogawa, RIKEN Brain Science Institute, Wako City, Japan) antibodies in the blocking solution for $1-3 \mathrm{~d}$ at $4^{\circ} \mathrm{C}$. They were rinsed in PBS, incubated in 1:100 FITC-conjugated donkey antirabbit IgG (Jackson ImmunoResearch, West Grove, PA) and 1:100 Cy3conjugated donkey anti-mouse IgG (Jackson ImmunoResearch) in the blocking serum, and rinsed in PBS. Free-floating sections were mounted on slides and air-dried. Sections were cleared with xylenes, coverslipped, and examined with an epifluorescent microscope (Axioplan 2; Zeiss, Jena, GmBH) and a confocal microscope (LSM 510; Zeiss, Jena, GmBH).

Electron microscopy. Pregnant mice (E17) were deeply anesthetized and killed by cervical dislocation. Their embryos were quickly extracted from the uterus and transcardially perfused under a stereomicroscope with chilled $4 \%$ formaldehyde (Polysciences, Warrington, PA) containing $0.2-3.0 \%$ glutaraldehyde (a perfusion system with a 30 -gauge needle was used). The brains were immediately dissected from the skulls in the same fixative and postfixed in the same fixative overnight at $4^{\circ} \mathrm{C}$. After postfixation, the brains were embedded in $3 \%$ agarose at $39^{\circ} \mathrm{C}$, cut on a vibratome at $50 \mu \mathrm{m}$ thickness into $0.1 \mathrm{M}$ phosphate buffer with ice cubes, and immediately processed with 5 -HT immunohistochemistry. Specifically, the sections were rinsed in PBS, $\mathrm{pH} 7.4$, and some of them were pretreated with $1 \%$ sodium borohydride in $\mathrm{PBS}$ for $30 \mathrm{~min}$, followed by rinses in PBS. The sections were then incubated in $0.3 \% \mathrm{H}_{2} \mathrm{O}_{2}$ in $\mathrm{PBS}$ for $20 \mathrm{~min}$, rinsed in PBS, and blocked in a solution containing 5\% normal goat serum, $1 \%$ bovine serum albumin, $0.1 \%$ glycine, and $0.1 \%$ L-lysine in PBS for $1 \mathrm{hr}$. The sections then were incubated in a rabbit anti-5-HT antibody (1:1000; Protos Biotech Corporation) in the blocking solution at $4^{\circ} \mathrm{C}$ overnight. They were rinsed in PBS, incubated in 1:200 biotinylated goat anti-rabbit IgG (Vector Laboratories, Burlingame, CA) in the blocking solution for $90 \mathrm{~min}$, rinsed in PBS, incubated in 1:100 ABC (Vector) in PBS for $1 \mathrm{hr}$, and rinsed in PBS, followed by a few rinses in $0.05 \mathrm{~m}$ Tris buffer (TB), pH 7.4. They were developed in $0.05 \% 3,3^{\prime}$ diaminobenzidine (DAB) with $0.04 \% \mathrm{NH}_{4} \mathrm{Cl}, 0.016 \mathrm{mg} / \mathrm{ml}$ glucose oxidase (catalog \#G-2133, type III; Sigma, St. Louis, MO), and $0.2 \% \beta$-Dglucose in TB for $5 \mathrm{~min}$. They were rinsed in TB, osmicated with $1 \%$ $\mathrm{OsO}_{4}$ in $\mathrm{TB}$ for $1 \mathrm{hr}$, rinsed in $\mathrm{TB}$, and stored overnight at $4^{\circ} \mathrm{C}$. They were then dehydrated through a series of graded ethanols, lightly contrasted with uranyl acetate, and embedded in Durcupan (Electron Microscopy Sciences, Fort Washington, PA). Punches containing DAB-labeled fibers in the MZ were excised, ultrasectioned at $70 \mathrm{~nm}$ onto single-slot grids, and examined with a JEOL (Tokyo, Japan) 1010 electron microscope.

5-Methoxtryptamine injections. The embryonic serotonergic system was perturbed by using a procedure developed by Shemer et al. (1991) and Kahne et al. (2002). Starting at E12, timed-pregnant mice were injected (1 mg/kg, s.c.) with 5-methoxytryptamine (5-MT; catalog \#M7002; Sigma), which was dissolved in bacteriostatic saline at 0.25 $\mathrm{mg} / \mathrm{ml}$ and stored in aliquots at $-20^{\circ} \mathrm{C}$. Control mice were injected with the same volume of bacteriostatic saline. The injections were done once a day every day until the mice delivered.

Western blotting. The brains of two newborn pups (P0) from each litter were quickly extracted and homogenized on ice with a pestle rotating at $2000 \mathrm{rpm}$ in a $2 \mathrm{ml}$ glass tube with $0.5 \mathrm{ml}$ of a homogenization buffer containing $25 \mathrm{~mm}$ HEPES, $150 \mathrm{~mm} \mathrm{KCl}$, and the EDTA-free protease inhibitor cocktail (Roche, Mannheim, Germany) in $0.05 \mathrm{M}$ Tris buffer, $\mathrm{pH}$ 7.4. The homogenate was centrifuged at $3000 \times \mathrm{g}$ for $15 \mathrm{~min}$ at $4^{\circ} \mathrm{C}$, and the supernatant was centrifuged again at $3000 \times g$ for $10 \mathrm{~min}$ at $4^{\circ} \mathrm{C}$. The collected supernatant (the final lysate) was stored at $-80^{\circ} \mathrm{C}$.

The blood of P0 pups was collected into EDTA-tubes (on ice). The blood of five pups from the same litter was collected into each tube. The blood samples were centrifuged in an Eppendorf microcentrifuge at $10,000 \mathrm{rpm}$ for $30 \mathrm{~min}$ at $4^{\circ} \mathrm{C}$, and the supernatant was centrifuged again at $14,000 \mathrm{rpm}$ for $10 \mathrm{~min}$. The serum supernatant was stored at $-80^{\circ} \mathrm{C}$.

The protein amounts in samples were estimated with a BCA Protein Assay reagent kit (Pierce, Rockford, IL). Brain lysates were thawed out on ice, and the loading samples were prepared by adding $50 \mu \mathrm{l}$ of $2 \times$ SDS sample buffer, $1 \mu$ l of 2-mercaptoethanol, and bromophenol blue to 50 $\mu \mathrm{l}$ of each lysate. Samples were boiled for $3 \mathrm{~min}$, and $60 \mu \mathrm{g}$ of protein $(\sim 23 \mu \mathrm{l})$ was loaded onto each lane of a $7.5 \%$ Tris- $\mathrm{HCl}$ pre-cast minigel (Bio-Rad Laboratories, Hercules, CA). Full Range Rainbow protein molecular weight markers (catalog number RPN800; Amersham Biosciences, Piscataway, NJ) were run in a few lanes of the gel. The proteins were separated by SDS-PAGE electrophoresis run at $200 \mathrm{~V}$ for $1 \mathrm{hr}$ at room temperature. The membrane then was rinsed for $5 \mathrm{~min}$ in transfer buffer, and proteins were electroblotted onto an Immobilon-P polyvinylidene difluoride $(0.45 \mu \mathrm{m})$ membrane (Millipore, Bedford, MA) at $100 \mathrm{~V}$ (first hour) and $75 \mathrm{~V}$ (second hour) in packed ice in a cold room. The transfer was assessed with the Ponceau S solution. The membrane was allowed to dry overnight and was immunoprobed for reelin. It was blocked in 5\% dry milk in PBS, incubated with a mouse anti-reelin $\operatorname{IgG}_{1} \kappa$ (G10; catalog \#MAB5364, diluted 1:100; Chemicon, Temecula, CA) in the blocking solution for $2 \mathrm{hr}$ at room temperature on a rocker, rinsed four times ( 5 min each) in PBS with $0.2 \%$ Tween 20 (PBST), incubated in 1:10,000 HRP-conjugated donkey anti-mouse IgG (Jackson ImmunoResearch) in the blocking solution for $1 \mathrm{hr}$, rinsed well in PBST followed by a few rinses in PBS, and reacted with the SuperSignal West Pico chemiluminescent solution (Pierce, Rockford, IL). The reelin bands were visualized with Hyperfilm ECL (Amersham Pharmacia Biotech, Buckinghamshire, UK).

Blood serums were diluted 1:5 with the homogenization buffer before adding $2 \times$ SDS sample buffer, 2-mercaptoethanol, and bromphenol blue. The prepared samples were boiled for $2 \mathrm{~min}$, and the separated proteins were electroblotted at $100 \mathrm{~V}$ for $2 \mathrm{hr}$ in a cold room. All the other procedures were the same as for the brain lysates.

Postnatal Nissl staining. For Nissl staining, pups (postnatal day 7) were perfused with chilled $4 \%$ paraformaldehyde. Their brains were extracted, postfixed in $4 \%$ paraformaldehyde at $4^{\circ} \mathrm{C}$ overnight, immersed in $30 \%$ sucrose at $4^{\circ} \mathrm{C}$ overnight, embedded in $20 \%$ gelatin, cut coronally on a freezing microtome at $50 \mu \mathrm{m}$ thickness, mounted on slides, stained with thionin, dehydrated through a series of graded alcohols, and coverslipped.

\section{Results}

At E17, two streams of serotonin-immunoreactive (5-HT+) fibers entered the anterior neocortex through the septum (Fig. $1 A)$. In coronal sections, they were visible as two 5-HT + bands: one in the $\mathrm{MZ}$ and the other below the cortical plate which, itself, was almost devoid of serotonergic fibers. The 5-HT+ fibers had strongly immunoreactive varicosities connected with less immunoreactive intervaricose segments. These fibers were more loosely dispersed in the deep band than in the MZ, where they appeared to be confined to this narrow layer. Some 5-HT + fibers crossed the cortical plate, but all of them ascended from the deep band. In contrast, we observed no 5-HT + fibers descending from the $\mathrm{MZ}$ to the deep band. Typical ascending fibers were strongly immunoreactive, did not branch, and often reached CR cells in the MZ (Fig. 1B). Confocal microscopy and three-dimensional analysis of obtained optical sections showed that ascending $5-\mathrm{HT}+$ fibers contacted CR cells (Fig. 1C). Some tangentially oriented fibers in the MZ also contacted CR cells (Fig. 1D), but we could not determine whether they belonged to the MZ band or were long tangential extensions of fibers that reached the MZ from the deep band.

To further investigate the contacts between 5-HT + fibers and CR cells, we immunolabeled cortical serotonergic afferents with 3,3'-diaminobenzidine (DAB) and analyzed them at the electron microscopy level. Immunoelectron microscopy of the embryonic 

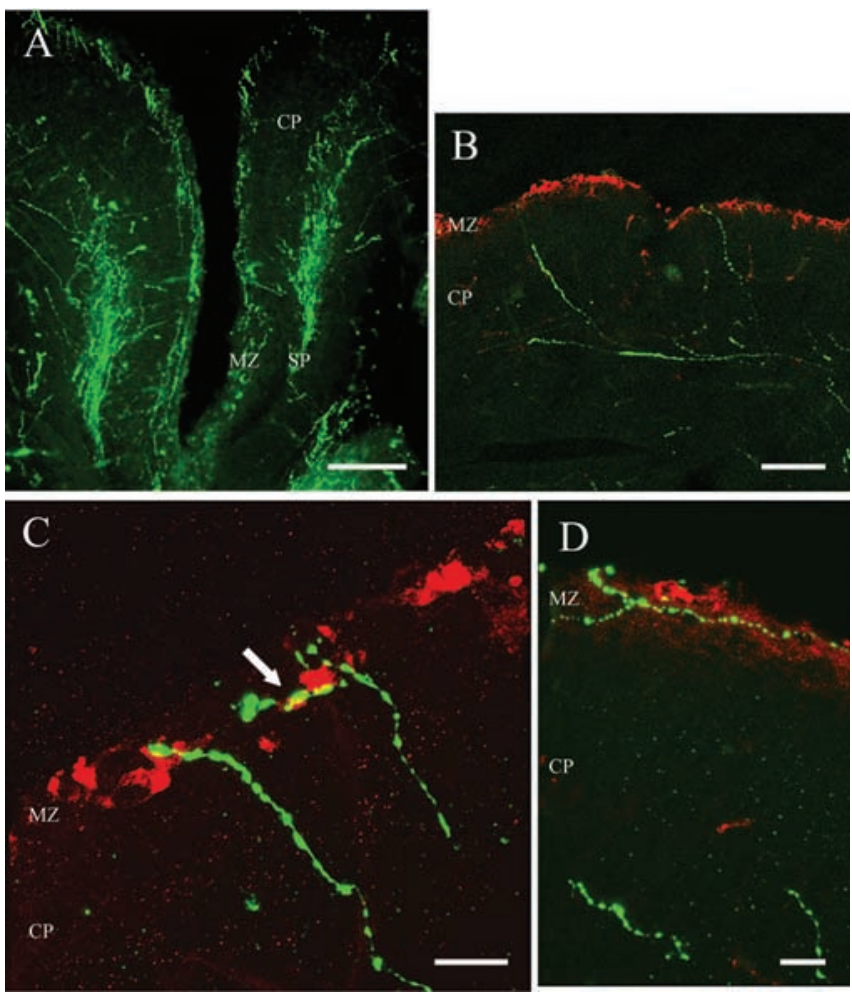

Figure 1. Serotonergic afferents (FITC, green) contact CR cells (Cy3, red) in the MZ of E17 embryos. $A$, Serotonergic fibers enter the developing cortex and form two bands, one in the marginal zone (MZ) and the other in the subplate (SP). B, Some serotonergic fibers in the SP traverse the cortical plate to reach the MZ. C, Confocal microphotograph of serotonergic fibers contacting CR cells in the MZ. The arrow indicates a point of contact confirmed by rotating the image in 3D. D, Horizontal serotonergic fibers contacting $C R$ cells in the MZ. Scale bars: $A, 200$ $\mu \mathrm{m} ; B, 100 \mu \mathrm{m} ; C, D, 20 \mu \mathrm{m}$.

mouse brain presents considerable challenges, because good preservation of the tissue is hard to achieve because of a large content of water, and high concentrations of glutaraldehyde suppress or completely abolish specific immunoreactivity. Therefore, to optimize our experiments, we analyzed the ultrastructure and 5-HT immunoreactivity of E17 brains fixed with 4\% paraformaldehyde containing a range of glutaraldehyde concentrations $(0.2-3.0 \%)$. Also, some brain sections were pretreated with sodium borohydride to recover some lost antigenicity. We found that $1 \%$ glutaraldehyde and pretreatment with sodium borohydride gave the optimum tissue preservation without abolishing immunoreactivity.

At E17, DAB-labeled $(5-\mathrm{HT}+)$ profiles were observed in the $\mathrm{MZ}$ and in the cortical plate (only the superficial cortical layers were analyzed). We assumed that the large, strongly 5-HTimmunoreactive profiles containing vesicles were serotonergic varicosities, as opposed to the thin and less immunoreactive intervaricose segments. This interpretation has been used by other researchers (Papadopoulos et al., 1987; Smiley and GoldmanRakic, 1996; Paspalas and Papadopoulos, 2001; Miceli et al., 2002). CR cell somata could be recognized by their position, elongated profiles oriented parallel to the pia, and by the characteristic features of their cytoplasm and nucleus (Derer et al., 2001). Most profiles of 5-HT + fibers were observed in the top part of the MZ (close to the pial edge of the MZ), containing the somata of CR cells (Fig. 2). Also, we frequently observed 5-HT+ fibers at the very pial edge of the MZ, "above" the somata of CR cells, where other somatic or dendritic profiles were very sparse or completely absent. It is possible that these fibers approached CR cells from the pial side, perhaps looping around them, as can be seen in a confocal image (Fig. 1D). Some 5-HT+ varicosities made putative synaptic contacts with the pial side of CR cell somata (Fig. 2C,D). Although heavy immunoprecipitation in these varicosities partly obscured their ultrastructure, we could measure some individual vesicles that were $\sim 40 \mathrm{~nm}$ in diameter. The postsynaptic elements of CR cells had no visible electrondense thickening. These axo-somatic contacts were relatively rare: we found no more than one such putative synapse in serial ultrathin sections obtained from a $50-\mu \mathrm{m}$-thick section. In contrast, 5-HT+ varicosities contacting dendrites of CR cells were more prevalent (Fig. 3). These contacts again appeared to be immature or specialized symmetric synapses with no postsynaptic thickening. Some of the presynaptic 5-HT + varicosities had clearly visible, densely stained small vesicles around $40 \mathrm{~nm}$ in diameter and a few large dense-cored vesicles of $\sim 120 \mathrm{~nm}$ in diameter (Fig. $3 D$ ). The ultrastructure of some $5-\mathrm{HT}+$ profiles closely resembled that of serotonergic growth cones, as described by Igvy-May et al. (1994). They contained small and large densecored vesicles, as well as large vacuoles (Fig. $3 E$ ). Some of these 5 -HT + profiles made contact with finger-like cytoplasmic protrusions of adjacent unlabeled dendrites or somata (Fig. 3E).

Having established the presence of contacts between early cortical serotonergic afferents and CR cells, we then asked what functional role they may play. Because CR cells secrete reelin, which is necessary for the normal development of both the laminar and columnar organization of the cerebral cortex, we perturbed the serotonergic system of mouse embryos by injecting pregnant mothers with 5-MT, a nonspecific 5-HT receptor agonist, and we used Western blots to determine reelin levels in their brains at birth (P0). 5-MT is endogenously colocalized with serotonin in many raphe neurons (Patel et al., 1986), and its subcutaneous injections have been previously shown to alter the prenatal serotonergic system and produce pups with behavioral deficits (Shemer et al., 1991; Lauder et al., 2000; Kahne et al., 2002). Two randomly chosen pups from each of the three treated and three control litters were used for brain lysates. In agreement with previous studies in lampreys, rats, mice, and humans (Smalheiser et al., 2000; Perez-Costas et al., 2002), several reelin isoforms were detected in the brain lysates of the mouse pups, with the most intense bands migrating to $\sim 175,73$, and $37 \mathrm{kDa}$. We found that the amount of the $175 \mathrm{kDa}$-reelin isoform was significantly lower in the brains of the pups whose mothers had been injected with 5-MT, as compared with controls $(p<0.05)$ (Fig. 4).

Because the manipulation of the serotonergic system altered brain reelin levels, it also could have an effect on the late embryonic stages of cortical laminar and columnar development, which depend on Cajal-Retzius cells and their transient networks (Marín-Padilla, 1998; Nishikawa et al., 2002; Luhmann et al., 2003). To see if supragranular cortical layers were affected in young pups (postnatal day 7) exposed to 5-MT before birth, we analyzed their presubicular cortex, which has visible supragranular columns in early postnatal life (Van Groen and Wyss, 1990; Nishikawa et al., 2002). In Nissl-stained sections, the supragranular layers of the presubicular columns appeared abnormal in pups whose mothers had been injected with 5-MT (Fig. 5). Although some periodical clustering of cells was still preserved, the supragranular columns appeared "smeared" and had cells between the columns, thus partially or fully merging with one another (Fig. $5 D, F)$. These observations were confirmed by counts performed by a trained person blind to the experimental conditions. For each treated and control case, a coronal section with the most 

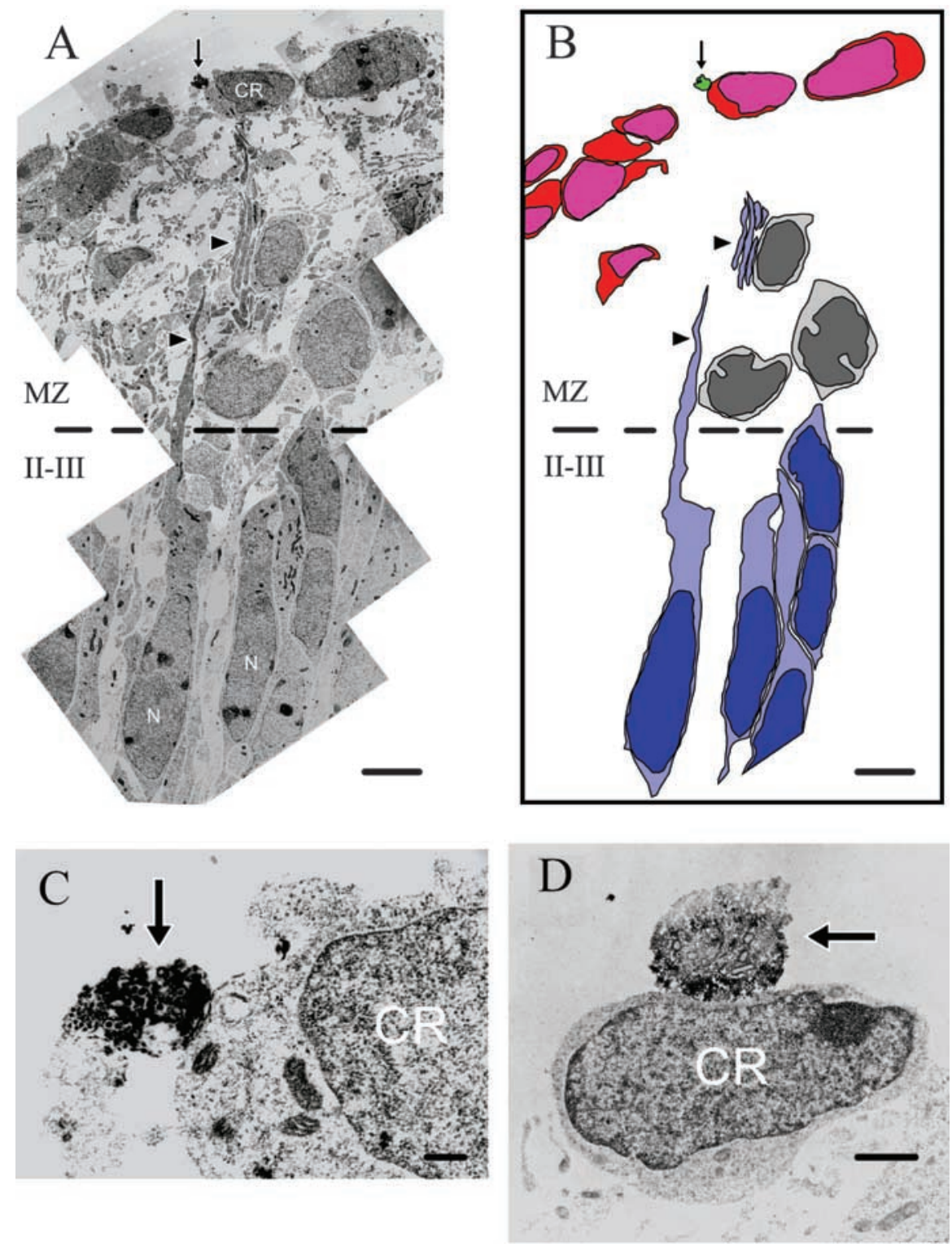

Figure 2. Ultrastructure of serotonergic axo-somatic contacts in the MZ of E17 embryos. $A$, Montage of electron micrographs showing a DAB-labeled (5-HT+) varicosity (arrow) contacting the soma of a CR cell. Note neuronal somata (N) in layers II-III and their processes (arrowheads) extended toward the MZ. B, Schematic representation of $A$. CR cells are colored in red, neurons in layers II-III in blue. The cells colored in gray may be tangentially migrating GABAergic interneurons, located at a certain distance from the CR cells, as previously demonstrated by Ang et al. (2003). C, Large magnification of the same 5 - HT + varicosity as in $A$ in an adjacent ultrasection. D, Another 5-HT + varicosity contacting the soma of a CR cell. Scale bars: $A, B, 4 \mu \mathrm{m} ; C, 250 \mathrm{~nm} ; D, 1 \mu \mathrm{m}$.

prominent presubicular columns was selected, and its image was digitized, coded, and randomly mixed with images from other cases. The columns were counted starting at the most lateral edge of the presubiculum until their darkly Nissl-stained supragranular "caps" merged and could no longer be distinguished as separate around the presubicular-postsubicular border (for the detailed anatomy, see Van Groen and Wyss, 1990). The mean number $( \pm$ SEM) of the presubicular columns in the treated pups was $6.30 \pm 0.37$ versus $8.80 \pm 0.86$ in the control pups $\left(t_{(8)}=\right.$ $-2.665 ; p<0.05)$.

Several recent studies have suggested that cortical minicolumns are abnormal in several debilitating neurological disorders such as schizophrenia, autism, and dyslexia (Buxhoeveden et al., 2000a; Casanova et al., 2002a,b,c,d; Casanova, 2003) and that reelin levels are altered in the brains and blood of autistic and schizophrenic patients (Fatemi et al., 2000, 2001a,b, 2002). Because our prenatal manipulation of the serotonin system altered brain reelin levels and perturbed postnatal presubicular columns, we were intrigued to see if it also altered reelin levels in blood serum. Consistent with previous reports in rats and humans (Smalheiser et al., 2000), several isoforms of serum reelin were detected, with the most intense bands migrating to $\sim 293$ and $43 \mathrm{kDa}$. The levels of the $293 \mathrm{kDa}$ isoform were lower in the pups whose serotonergic system had been prenatally disturbed with 5-MT $(p<$ 0.05) (Fig. 6).

\section{Discussion}

In the present study, we found that the earliest serotonergic afferents to the developing cerebral cortex establish synaptic contacts with CR cells and that this serotonergic input may be important for the normal development of the cerebral cortex. The pattern of the prenatal serotonergic innervation and reelin expression by CR cells during cortical development are conserved across mammalian species, including humans (Lidov and Molliver, 1982; Bruning et al., 1997; Smalheiser et al., 2000; Perez-Costas et al., 2002; Verney et al., 2002). Because the prenatal contacts between serotonergic afferents and CR cells are immature and, therefore, lack classical membrane specializations, their exact nature needs further elucidation. Our findings indicate that they are likely to be synaptic, because: (1) the serotonergic varicosities contained small $(\sim 40 \mathrm{~nm})$ and dense-cored vesicles $(\sim 120 \mathrm{~nm})$, which is typical of presynaptic serotonergic varicosities in the adult brain (Paspalas and Papadopoulos, 2001); (2) at least in the adult brain, most (if not all) serotonergic varicosities make overt synapses (Papadopoulos et al., 1987; de Lima et al., 1988; Parnavelas and Papadopoulos, 1989; Papadopoulos and Parnavelas, 1991; Paspalas and Papadopoulos, 2001); (3) even in the adult brain, the active zone of a typical serotonergic synapse is usually small and is often missed unless a complete set of serial sections are examined (Papadopoulos and Parnavelas, 1991). The absence of clear membrane specializations in the present study could also be attributable to the immaturity of the serotonergic synapses and to the loss of membrane integrity, which is difficult to preserve in embryonic brain tissue during fixation. Interestingly, axo-dendritic contacts between serotonergic afferents and CR cells were more frequent than axosomatic contacts, which is also typical for serotonergic synapses in the rodent cortex (Papadopoulos et al., 1987).

Our results demonstrate that serotonergic afferents establish putative synaptic contacts with CR cells even before neuronal migration is complete and before serotonergic fibers have massively invaded the cortical plate. The early formation of these 
synapses may be facilitated by the presence of the fully developed presynaptic machinery in serotonergic growth cones (IgvyMay et al., 1994). However, it is not known when and how CR cells can detect serotonergic signals and whether CR cells express serotonin receptors. CR cells express an array of receptors for other neurotransmitters, such as glutamate, GABA, glycine, and norepinephrine (Schwartz et al., 1998; Lu et al., 2001; Radnikow et al., 2002, Luhmann et al., 2003; Soda et al., 2003). The absence of published reports on serotonin receptors on CR cells appears to be attributable to the availability of adequate serotonin receptor antibodies. We have tried and failed to achieve specific labeling in the embryonic and adult brain using commercial 5- $\mathrm{HT}_{1 \mathrm{~A}}$ antibodies (Chemicon; Calbiochem) under various perfusion and incubation conditions. However, it is likely that CR cells express $5-\mathrm{HT}_{1 \mathrm{~A}}$ receptors, because (1) early postnatal CR cells hyperpolarize when exposed to serotonin (Foehring et al., 2002), which is typical of the $5-\mathrm{HT}_{1 \mathrm{~A}}$ receptors, and (2) several studies have shown that $5-\mathrm{HT}_{1 \mathrm{~A}}$ receptors exhibit a transient peak in the cortical and cerebellar development perinatally (Bar-Peled et al., 1991; del Olmo et al., 1994), at the approximate time when serotonergic afferents make contacts with CR cells. CR cells may also express other 5-HT receptors, such as the $5-\mathrm{HT}_{3}$ receptor, as has been proposed by Tecott et al. (1995).

To assess the role of the contacts between serotonergic afferents and CR cells, we manipulated the serotonin system before birth by administering 5-MT, a methylated serotonin derivative, which is also an endogenous trace amine in the brain and a nonspecific 5- $\mathrm{HT}_{1}$ and 5- $\mathrm{HT}_{2}$ receptor agonist (Patel et al., 1986; Yu et al., 2003). Prenatal administration of 5-MT has been shown to affect the sprouting of serotonergic fibers and/or the expression of the serotonin transporter at serotonergic terminals (Shemer et al., 1991) and alter the expression of the $5-\mathrm{HT}_{1 \mathrm{~A}}$ receptor (Lauder et al., 2000). It should be noted that other pharmacological and genetic manipulations of the embryonic serotonergic system are available, such as blocking embryonic 5-HT synthesis with p-chlorophenylalanine (pCPA) (Lauder and Krebs, 1978; Lauder et al., 1985), or knocking out genes that are necessary for the development of serotonergic neurons (Hendricks et al., 2003) or serotonergic cortical projections (Donovan et al., 2002). However, prenatal treatment with 5-MT has the following advantages: (1) 5-MT is endogeneously present in the brain (Patel et al., 1986); (2) its effect on cortical serotonergic fibers is transient and gradually disappears postnatally (Shemer et al., 1991); (3) the injections are easy to make, and treated mice deliver without the
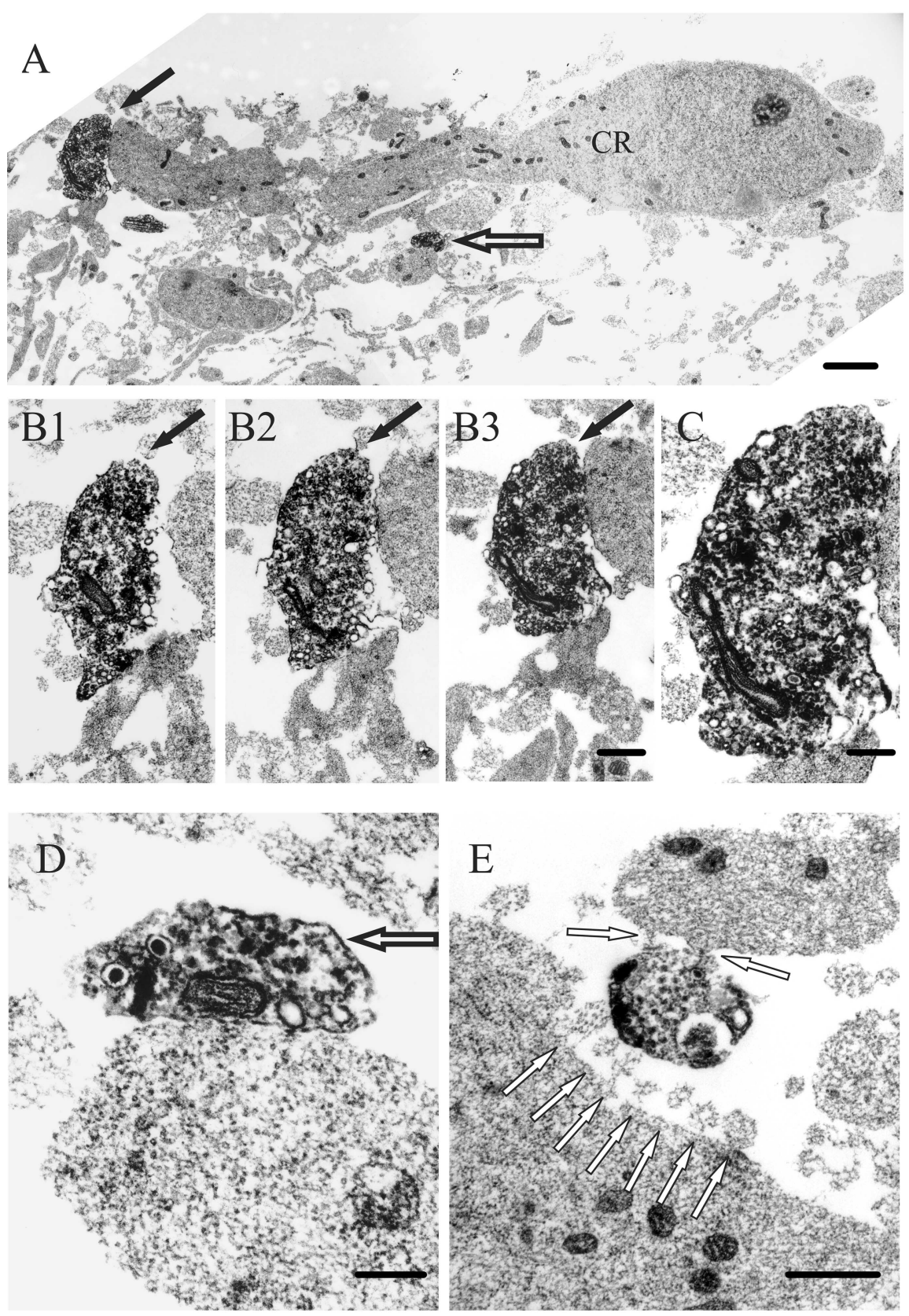

Figure 3. Ultrastructure of serotonergic axo-dendritic contacts in the MZ of E17 embryos. $A$, Montage of electron micrographs of a CR cell with adjacent dendrites making contacts with two 5-HT + varicosities (arrows). The top of the montage corresponds to the pial side of the MZ. B1-B3, In serial ultrathin sections, a 5-HT + varicosity (indicated with black arrow in $A$ and $B 1-B 3$ ) approaches and makes contact with a putative CR dendrite. $C$, Higher magnification of the same 5 -HT + varicosity as in $B 3$. D, Contact between a 5 - HT + varicosity (indicated by an open arrow in $A$ and $D$ ) and a putative $(R$ dendrite. Note the darkly stained small vesicles and some large dense-cored vesicles in the 5-HT + varicosity. E, 5-HT + profile, possibly a growth cone, making contact with an adjacent CR dendrite (top of the panel) and a CR soma (bottom) in the MZ. Note the finger-like cytoplasmic protrusions of the soma (white arrows). Also, note the accumulation of darkly labeled vesicles on the left hand side of the 5-HT+ profile. Scale bars: $A, 1 \mu \mathrm{m} ; B 1-B 3,500 \mathrm{~nm} ; C, 250 \mathrm{~nm} ; D, 200 \mathrm{~nm} ; E, 500 \mathrm{~nm}$.

delay observed in pCPA-treated animals (Lauder and Krebs, 1978); (4) it mimics the elevated levels of blood 5-HT in autism and produces rat pups that have some "autistic-like" symptoms (Kahne et al., 2002).

In the present study, the manipulation of the prenatal serotonergic system with 5-MT led to altered reelin levels in the brains of newborn pups, with the $175 \mathrm{kDa}$ isoform being less abundant in the prenatally treated pups. Several reelin isoforms of different molecular weight are consistently detected in Western blots in 

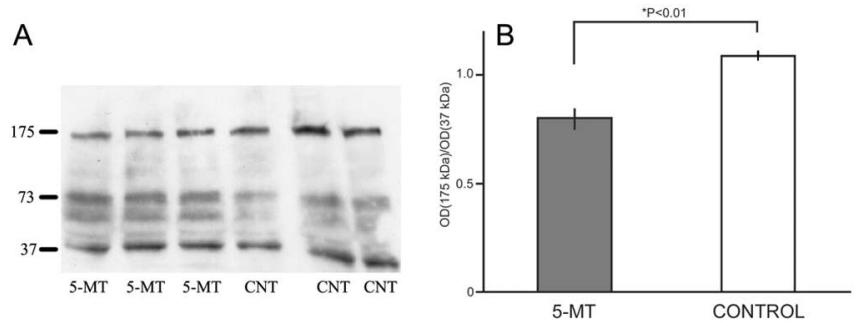

Figure 4. Reelin levels in the brains of newborn pups prenatally treated with 5-MT. Western blots of $\mathrm{P} 0$ brains immunoprobed for reelin $(A)$ and the corresponding densities of the $175 \mathrm{kDa}$ bands in the treated and control animals $(B)$.
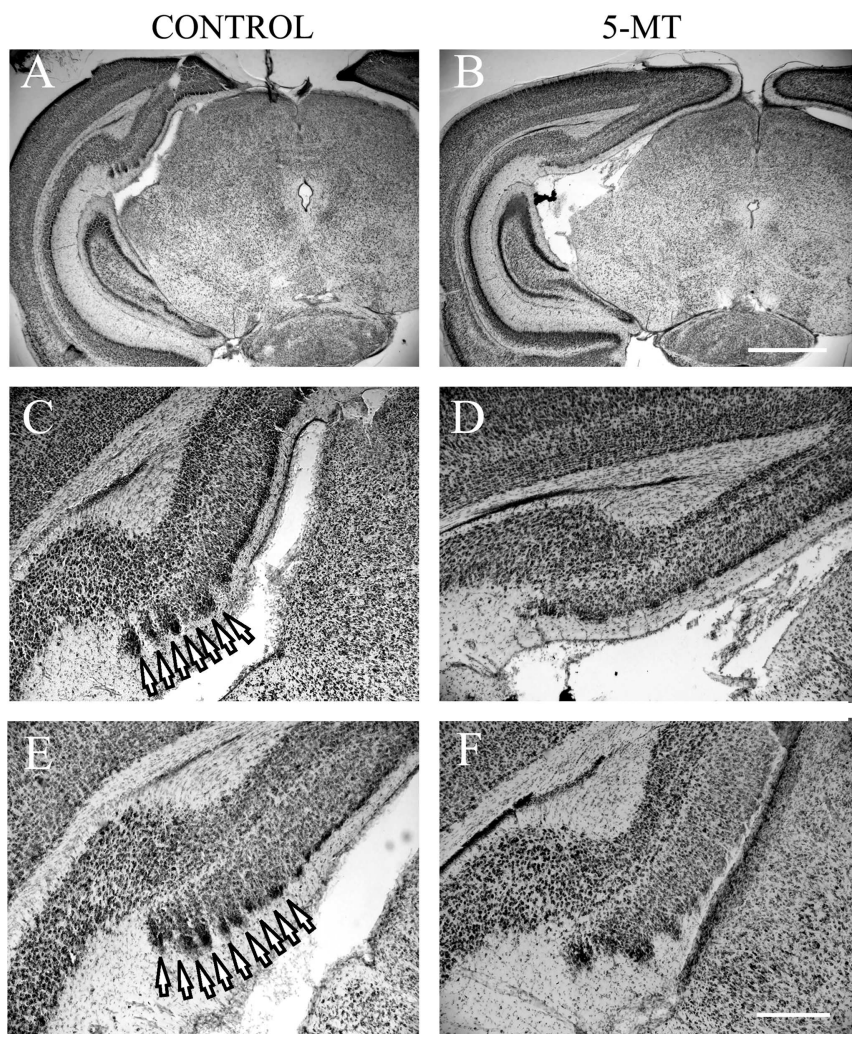

Figure 5. Presubicular cortex of pups (postnatal day 7) prenatally exposed to 5-MT. Niss staining of the presubicular cortex of P7 pups treated with saline $(A, C, E)$ or 5-MT $(B, D, F)$ during pregnancy (E12 through term). $C, D$, High magnification of $A$ and $B$, correspondingly. Note the well defined presubicular columns (arrows) in the saline-treated animals. Scale bars: $A, B, 1$ $\mathrm{mm} ; C-F, 300 \mu \mathrm{m}$.

various vertebrate species (Smalheiser et al., 2000; Perez-Costas et al., 2002). These forms appear to be the result of proteolytic cleavage of the full-length reelin molecule (Tissir and Goffinet, 2003). Specific isoforms have been linked to several neurological disorders (Fatemi et al., 2001a,b, 2002; Fatemi, 2002). Because we estimated reelin levels in the whole embryonic brain and because CR cells are not the only cells in the embryonic brain that can express reelin (Alcantara et al., 1998; Nishikawa et al., 1999), it is possible that the expression of reelin by other cells was also altered. However, it is unlikely that the differences in reelin expression in the brain lysates was attributable to contamination with blood reelin because its prevalent isoforms in the brain and serum are distinctly different, as shown previously (Smalheiser et al., 2000) and in the present study. Therefore, we suggest that the 5-MT-induced disruption of the normal serotonergic input to CR cells altered their reelin expression. Because several studies
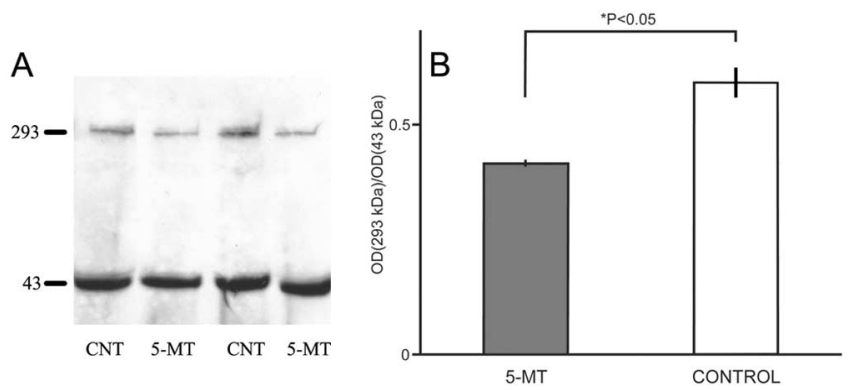

Figure 6. Reelin levels in the blood serum of newborn pups prenatally exposed to 5-MT. Western blots of $\mathrm{PO}$ blood serum immunoprobed for reelin $(A)$ and the corresponding densities of the $293 \mathrm{kDa}$ bands in the treated and control animals $(B)$.

have shown that altered reelin expression in corticogenesis disrupts the normal laminar and columnar organization of the cerebral cortex (Ogawa et al., 1995; Nishikawa et al., 2002), our findings suggest that embryonic serotonergic disturbances may have an impact on the late stages of corticogenesis. Interestingly, it has recently been shown that another monoamine, norepinephrine, also has effects on developing CR cells (Naqui et al. 1999).

The mouse presubicular cortex has been previously used to study the development of the basic columnar organization in the entire cerebral cortex (Nishikawa et al., 1999). Although the presubicular cortex is anatomically distinct from the neocortex (Van Groen and Wyss, 1990), the basic development of its layers is similar to that of the neocortex. In addition, the development of its columns depends on reelin secreted by CR cells (Nishikawa et al., 1999) and, therefore, may be relevant to understanding the development of neocortical microcolumns (they are not readily visible in the mouse cortex). Because we observed abnormal columns in the presubicular cortex of pups whose serotonergic system had been prenatally perturbed, serotonergic signaling to CR cells may play a more important role in cortical development than was previously thought. In the supragranular layers, neighboring columns of treated animals often merged because of ectopic cells between the columns, which is consistent with a report that the intercolumnar spaces of the presubicular cortex correspond to reelin-rich areas in the MZ of the normal mouse (Nishikawa et al., 2002) and with our observation of lower reelin levels in the 5-MT-treated mice. Those relatively subtle alterations in cortical organization are consistent with the fact that serotonergic afferents reach the cortex at the latest stages of cortical development and, because most of the radially migrating neurons have already settled in their final laminar positions, they cannot affect reelin levels early enough to cause a major malformation of cortical layers. However, the latest wave of radially migrating neurons destined for supragranular layers and a significant percentage of tangentially migrating neurons, as well as the onset of the thalamocortical ingrowth, may still be affected. We cannot rule out the possibility that 5-MT treatment had some effect on transient 5-HT uptake by nonserotonergic thalamocortical terminals (Lebrand et al., 1996, 1998). However, thalamocortical innervation is essentially postnatal, whereas newborn pups were not treated with 5-MT, and Shemer et al. (1991) have shown that after 5-MT injections, 5-HT uptake starts to normalize immediately after birth.

It is intriguing to consider that the arrival of serotonergic afferents in the cortex may alter reelin levels early enough to have a major impact on the formation of functional cortical columns, because: (1) the formation of cortical columns continues into 
early postnatal life and is controlled by transient cortical networks dependent on CR cells (Luhmann et al., 2003) and reelin secretion (Nishikawa et al., 2002); and (2) the development of cortical columns depends on GABAergic interneurons (Buxhoeveden et al., 2000b; Casanova et al., 2002c) that establish their connections with projection neurons at the late stages of corticogenesis and that may be at least partially guided by CR cells (Shinozaki et al., 2002; Ang et al., 2003). The columnar organization may be particularly vulnerable in the large and convoluted primate forebrain, where it is much more prominent during migratory phases of cortical development (Sidman and Rakic, 1973; Rakic, 1988, 2003).

Considering the fact that the correct allocation of neurons within the cortical laminae and columns is essential for the normal cortical columnar organization and subsequent normal brain function (Rakic, 1988), this study implicates a possible common pathway how inborn serotonergic disturbances may affect brain development. Functional failures at several points of this pathway (i.e., a mutation of the serotonin transporter gene, failures of serotonergic transmission at CR cells, a mutation of the reeler gene) may result in similar disruption of the normal cortical organization, which would support the "common neurochemical mechanistic failure" hypothesis (Chugani, 2002). Moreover, several recent studies indicated that various debilitating neurological disorders that have been linked to the serotonergic system, such as schizophrenia and autism, may be at least partially caused by developmental abnormalities of cortical columns (Selemon and Goldman-Rakic, 1999; Buxhoeveden et al., 2000a; Casanova et al., 2002a,b,c; Casanova, 2003). Our results show that embryonic serotonergic disturbances may be important for the development of some of these cortical abnormalities and, therefore, may offer new insights into the etiology of these disorders.

\section{References}

Alcantara S, Ruiz M, D’Arcangelo G, Ezan F, de Lecea L, Curran T, Sotelo C, Soriano E (1998) Regional and cellular patterns of reelin expression in the forebrain of the developing and adult mouse. J Neurosci 18:7779-7799.

Anderson GM, Horne WC, Chatterjee D, Cohen DJ (1990) The hyperserotonemia of autism. Ann NY Acad Sci 600:331-340.

Ang Jr ES, Haydar TF, Gluncic V, Rakic P (2003) Four-dimensional migratory coordinates of GABAergic interneurons in the developing mouse cortex. J Neurosci 23:5805-5815.

Azmitia E (2001) Modern views on an ancient chemical: serotonin effects on cell proliferation, maturation, and apoptosis. Brain Res Bull 56:413-424.

Bar-Peled O, Gross-Isseroff R, Ben-Hur H, Hoskins I, Groner Y, Biegon A (1991) Fetal human brain exhibits a prenatal peak in the density of serotonin 5- $\mathrm{HT}_{1 \mathrm{~A}}$ receptors. Neurosci Lett 127:173-176.

Bruning G, Liangos O, Baumgarten HG (1997) Prenatal development of the serotonin transporter in mouse brain. Cell Tissue Res 289:211-221.

Buxhoeveden DP, Casanova MF (2002) The minicolumn hypothesis in neuroscience. Brain 125:935-951.

Buxhoeveden DP, Roy E, Switala A, Casanova MF (2000a) Reduced interneuronal space in schizophrenia. Biol Psychiatry 47:681-682.

Buxhoeveden DP, Switala AE, Roy E, Casanova MF (2000b) Quantitative analysis of cell columns in the cerebral cortex. J Neurosci Methods 97:7-17.

Casanova MF (2003) Modular concepts of brain organization and the neuropathology of psychiatric conditions. Psychiatry Res 118:101-102.

Casanova MF, Buxhoeveden DP, Brown C (2002a) Clinical and macroscopic correlates of minicolumnar pathology in autism. J Child Neurol 17:692-695.

Casanova MF, Buxhoeveden DP, Cohen M, Switala AE, Roy EL (2002b) Minicolumnar pathology in dyslexia. Ann Neurol 52:108-110.

Casanova MF, Buxhoeveden DP, Switala AE, Roy E (2002c) Minicolumnar pathology in autism. Neurology 58:428-432.
Casanova MF, Buxhoeveden DP, Switala AE, Roy E (2002d) Asperger's syndrome and cortical neuropathology. J Child Neurol 17:142-145.

Chugani DC (2002) Role of altered brain serotonin mechanisms in autism. Mol Psychiatry 7 [Suppl 2]:S16-S17.

Chugani DC, Muzik O, Behen M, Rothermel R, Janisse JJ, Lee J, Chugani HT (1999) Developmental changes in brain serotonin synthesis capacity in autistic and nonautistic children. Ann Neurol 45:287-295.

Dean B (2003) The cortical serotonin2A receptor and the pathology of schizophrenia: a likely accomplice. J Neurochem 85:1-13.

de Lima AD, Bloom FE, Morrison JH (1988) Synaptic organization of serotonin-immunoreactive fibers in primary visual cortex of the macaque monkey. J Comp Neurol 274:280-294.

del Olmo E, Diaz A, Guirao-Pineyro M, del Arco C, Pascual J, Pazos A (1994) Transient localization of $5-\mathrm{HT}_{1 \mathrm{~A}}$ receptors in human cerebellum during development. Neurosci Lett 166:149-152.

Derer P, Derer M, Goffinet A (2001) Axonal secretion of reelin by CajalRetzius cells: Evidence from comparison of normal and Reln ${ }^{\text {Orl }}$ mutant mice. J Comp Neurol 440:136-143.

Donovan SL, Mamounas LA, Andrews AM, Blue ME, McCasland JS (2002) GAP-43 is critical for normal development of the serotonergic innervation in forebrain. J Neurosci 22:3543-3552.

Dulabon L, Olson EC, Taglienti MG, Eisenhuth S, McGrath B, Walsh CA, Kreidberg JA, Anton ES (2000) Reelin binds $\alpha 3 \beta 1$ integrin and inhibits neuronal migration. Neuron 27:33-44.

Eastwood SL, Harrison PJ (2003) Interstitial white matter neurons express less reelin and are abnormally distributed in schizophrenia: towards an integration of molecular and morphological aspects of the neurodevelopmental hypothesis. Mol Psychiatry 8:821-831.

Fatemi SH (2002) The role of reelin in pathology of autism. Mol Psychiatry 7:919-920.

Fatemi SH, Earle JA, McMenomy T (2000) Reduction in reelin immunoreactivity in hippocampus of subjects with schizophrenia, bipolar disorder and major depression. Mol Psychiatry 5:654-663.

Fatemi SH, Kroll JL, Stary JM (2001a) Altered levels of reelin and its isoforms in schizophrenia and mood disorders. NeuroReport 12:3209-3215.

Fatemi SH, Stary JM, Halt AR, Realmuto GR (2001b) Dysregulation of reelin and Bcl-2 proteins in autistic cerebellum. J Autism Dev Disord 31:529-535.

Fatemi SH, Stary JM, Egan EA (2002) Reduced blood levels of reelin as a vulnerability factor in pathophysiology of autistic disorder. Cell Mol Neurobiol 22:139-151.

Foehring RC, van Brederode JFM, Kinney GA, Spain WJ (2002) Serotonergic modulation of supragranular neurons in rat sensorimotor cortex. J Neurosci 22:8238-8250.

Hack I, Bancila M, Loulier K, Caroll P, Cremer H (2002) Reelin is a detachment signal in tangential chain-migration during postnatal neurogenesis. Nat Neurosci 5:939-945.

Hendricks TJ, Fyodorov DV, Wegman LJ, Lelutiu NB, Pemek EA, Yamamoto B, Silver J, Weeber EJ, Sweatt JD, Deneris ES (2003) Pet-1 ETS gene plays a critical role in 5-HT neuron development and is required for normal anxiety-like and aggressive behavior. Neuron 37:233-247.

Igvy-May N, Tamir H, Gershon MD (1994) Synaptic properties of serotonergic growth cones in developing rat brain. J Neurosci 14:1011-1029.

Jones EG (2000) Microcolumns in the cerebral cortex. Proc Natl Acad Sci USA 97:5019-5021.

Kahne D, Tudorica A, Borella A, Shapiro L, Johnstone F, Huang, WhitakerAzmitia PM (2002) Behavioral and magnetic resonance spectroscopic studies in the rat hyperserotonemic model of autism. Physiol Behav 75:403-410.

Lauder JM, Krebs H (1978) Serotonin as a differentiation signal in early neurogenesis. Dev Neurosci 1:15-30.

Lauder JM, Towle AC, Patrick K, Henderson P, Krebs H (1985) Decreased serotonin content of embryonic raphe neurons following maternal administration of $p$-chlorophenylalanine: a quantitative immunocytochemical study. Dev Brain Res 20:107-114.

Lauder JM, Liu J, Grayson DR (2000) In utero exposure to serotonergic drugs alters neonatal expression of $5-\mathrm{HT}_{1 \mathrm{~A}}$ receptor transcripts: a quantitative RT-PCR study. Int J Dev Neurosci 18:171-176.

Lebrand C, Cases O, Adelbrecht C, Doye A, Alvarez C, Mestikawy SE, Seif I, Gaspar P (1996) Transient uptake and storage of serotonin in developing thalamic neurons. Neuron 17:991-1003. 
Lebrand C, Cases O, Wehrle R, Blakely RD, Edwards RH, Gaspar P (1998) Transient developmental expression of monoamine transporters in the rodent forebrain. J Comp Neurol 401:506-524.

Lidov HG, Molliver ME (1982) An immunohistochemical study of serotonin neuron development in the rat: ascending pathways and terminal fields. Brain Res Bull 8:389-430.

Lu S-M, Zecevic N, Yeh HH (2001) Distinct NMDA and AMPA receptormediated responses in mouse and human Cajal-Retzius cells. J Neurophysiol 86:2642-2646.

Luhmann HJ, Hanganu I, Kilb W (2003) Cellular physiology of the neonatal rat cerebral cortex. Brain Res Bull 60:345-353.

Marín-Padilla M (1998) Cajal-Retzius cells and the development of the neocortex. Trends Neurosci 21:64-71.

Miceli D, Reperant J, Rio J-P, Hains P, Medina M (2002) Serotonin immunoreactivity in the retinal projecting isthmo-optic nucleus and evidence of brainstem raphe connections in the pigeon. Brain Res 958:122-129.

Naqui SZH, Harris BS, Thomaidou D, Parnavelas JG (1999) The noradrenergic system influences the fate of Cajal-Retzius cells in the developing cerebral cortex. Dev Brain Res 113:75-82.

Nishikawa S, Goto S, Hamasaki T, Ogawa M, Ushio Y (1999) Transient and compartmental expression of the reeler gene product reelin in the developing rat striatum. Brain Res 850:244-248.

Nishikawa S, Goto S, Hamasaki T, Kazumichi Y, Ushio Y (2002) Involvement of reelin and Cajal-Retzius cells in the developmental formation of vertical columnar structures in the cerebral cortex: evidence from the study of mouse presubicular cortex. Cereb Cortex 12:1024-1030.

Ogawa M, Miyata T, Nakajima K, Yagyu K, Seike M, Ikenaka K, Yamamoto H, Mikoshiba K (1995) The reeler gene-associated antigen on Cajal-Retzius neurons is a crucial molecule for laminar organization of cortical neurons. Neuron 14:899-912.

Papadopoulos GC, Parnavelas JG (1991) Monoamine systems in the cerebral cortex: evidence for anatomical specificity. Prog Neurobiol 36:195-200.

Papadopoulos GC, Parnavelas JG, Buijs R (1987) Monoaminergic fibers form conventional synapses in the cerebral cortex. Neurosci Lett 76:275-279.

Parnavelas JG, Papadopoulos GC (1989) The monoaminergic innervation of the cerebral cortex is not diffuse and nonspecific. Trends Neurosci 12:315-319.

Paspalas CD, Papadopoulos GC (2001) Serotoninergic afferents preferentially innervate distinct subclasses of peptidergic interneurons in the rat visual cortex. Brain Res 891:158-167.

Patel S, Dulluc J, Geffard M (1986) Comparison of serotonin and 5-methoxytryptamine immunoreactivity in rat raphe nuclei. Histochemistry 85:259-263.

Perez-Costas E, Melendez-Ferro M, Santos Y, Anadon R, Rodicio MC, Caruncho HJ (2002) Reelin immunoreactivity in the larval sea lamprey brain. J Chem Neuroanat 23:211-221.

Persico AM, Baldi A, Dell'Acqua ML, Moessner R, Murphy DL, Lesch K-P, Keller F (2003) Reduced programmed cell death in brains of serotonin transporter knockout mice. NeuroReport 14:341-344.

Radnikow G, Feldmeyer D, Lubke J (2002) Axonal projection, input and output synapses, and synaptic physiology of Cajal-Retzius cells in the developing rat neocortex. J Neurosci 22:6908-6919.

Rakic P (1988) Specification of cerebral cortical areas. Science 241:170-176.

Rakic P (2003) Developmental and evolutionary adaptations of radial glial cells. Cereb Cortex 13:541-549.

Rakic S, Zecevic N (2003) Emergic complexity of layer I in human cerebral cortex. Cereb Cortex 13:1072-1083.

Schwartz TH, Rabinowitz D, Unni V, Kumar VS, Smetters DK, Tsiola A, Yuste R (1998) Networks of coactive neurons in developing layer 1. Neuron 20:541-552.

Selemon LD, Goldman-Rakic PS (1999) The reduced neuropil hypothesis: a circuit based model of schizophrenia. Biol Psychiatry 45:17-25.

Shemer AV, Azmitia EC, Whitaker-Azmitia PM (1991) Dose-related effects of prenatal 5-methoxytryptamine (5-MT) on development of serotonin terminal density and behavior. Dev Brain Res 59:59-63.

Shinozaki K, Miyagi T, Yoshida M, Miyata T, Ogawa M, Aizawa S, Suda Y (2002) Absence of Cajal-Retzius cells and subplate neurons associated with defects of tangential cell migration from ganglionic eminence in Emx1/2 double mutant cerebral cortex. Development 129:3479-3492.

Sidman RL, Rakic P (1973) Neuronal migration with special reference to developing human brain: a review. Brain Res 62:1-35.

Smalheiser NR, Costa E, Guidotti A, Impagnatiello F, Auta J, Lacor P, Kriho V, Pappas GD (2000) Expression of reelin in adult mammalian blood, liver, pituitary pars intermedia, and adrenal chromaffin cells. Proc Nat Acad USA 97:1281-1286.

Smiley JF, Goldman-Rakic PS (1996) Serotonergic axons in monkey prefrontal cerebral cortex synapse predominantly on interneurons as demonstrated by serial section electron microscopy. J Comp Neurol 367:431-443.

Soda T, Nakashima R, Watanabe D, Nakajima K, Pastan I, Nakanishi S (2003) Segregation and coactivation of developing neocortical layer I neurons. J Neurosci 23:6272-6279.

Tecott L, Shtrom S, Julius D (1995) Expression of a serotonin-gated ion channel in embryonic neural and nonneural tissues. Mol Cell Neurosci 6:43-55.

Tissir F, Goffinet AM (2003) Reelin and brain development. Nat Rev Neurosci 4:496-505.

Van Groen T, Wyss JM (1990) The postsubicular cortex in the rat: characterization of the fourth region of the subicular cortex and its connections. Brain Res 529:165-177.

Verney C, Lebrand C, Gaspar P (2002) Changing distribution of monoaminergic markers in the developing human cerebral cortex with special emphasis on the serotonin transporter. Anat Rec 267:87-93.

Wallace JA, Lauder JM (1983) Development of the serotonergic system in the rat embryo: an immunocytochemical study. Brain Res Bull 10:459-479.

Whitaker-Azmitia PM (2001) Serotonin and brain development: Role in human developmental diseases. Brain Res Bull 56:479-485.

Whitaker-Azmitia PM, Druse M, Walker P, Lauder JM (1996) Serotonin as a developmental signal. Behav Brain Res 73:19-29.

Yu A-M, Idle JR, Byrd LG, Krausz KW, Kupfer A, Gonzalez FJ (2003) Regeneration of serotonin from 5-methoxytryptamine by polymorphic human CYP2D6. Pharmacogenetics 13:173-181. 